Nova Southeastern University

\title{
Catch Rates with Variable Strength Circle Hooks in the Hawaii-Based Tuna Longline Fishery
}

\author{
Keith A. Bigelow \\ Nova Southeastern University \\ David W. Kerstetter \\ Nova Southeastern University, kerstett@nova.edu \\ Matthew G. Dancho \\ Nova Southeastern University \\ Jamie A. Marchetti \\ Nova Southeastern University
}

Find out more information about Nova Southeastern University and the Halmos College of Natural Sciences and Oceanography.

Follow this and additional works at: https://nsuworks.nova.edu/occ_facarticles

Part of the Marine Biology Commons, and the Oceanography and Atmospheric Sciences and Meteorology Commons

\section{NSUWorks Citation}

Keith A. Bigelow, David W. Kerstetter, Matthew G. Dancho, and Jamie A. Marchetti. 2012. Catch Rates with Variable Strength Circle Hooks in the Hawaii-Based Tuna Longline Fishery .Bulletin of Marine Science , (3) : 425 -447. https://nsuworks.nova.edu/ occ_facarticles/538.

This Article is brought to you for free and open access by the Department of Marine and Environmental Sciences at NSUWorks. It has been accepted for inclusion in Marine \& Environmental Sciences Faculty Articles by an authorized administrator of NSUWorks. For more information, please contact nsuworks@nova.edu. 


\title{
CATCH RATES WITH VARIABLE STRENGTH CIRCLE HOOKS IN THE HAWAII-BASED TUNA LONGLINE FISHERY
}

\author{
Keith A Bigelow, David W Kerstetter, \\ Matthew G Dancho, and Jamie A Marchetti
}

\begin{abstract}
The Hawaii-based deep-set longline fleet targets bigeye tuna [Thunnus obesus (Lowe, 1839)] and infrequently takes false killer whales [FKW, Pseudorca crassidens (Owen, 1846)] as bycatch. From 2004 to 2008 with 20\%-26\% observer coverage, nine mortalities of and serious injuries to FKW were documented in the deep-set fishery in the Hawaii EEZ, yielding a mean take estimate of 7.3 animals $\mathrm{yr}^{-1}$. Weak hook technology can utilize the size disparity between target and other species to promote the release of larger non-target species. Four vessels tested the catch efficacy and size selectivity of $15 / 0$ "strong" circle hooks ( $4.5 \mathrm{~mm}$ wire diameter) that straighten at $138 \mathrm{~kg}$ of pull in comparison with $15 / 0$ "weak" $(4.0 \mathrm{~mm})$ that straighten at $93 \mathrm{~kg}$ of pull. Vessels alternated hook types throughout the longline gear and maintained a 1:1 ratio of strong and weak hooks. Observers monitored a total of 127 sets of 302,738 hooks, and randomization tests were applied to test for significant differences in catch for 22 species. There were no significant catch differences for bigeye tuna; however, there may be limitations to these inferences because trials were not conducted during spring when larger bigeye tuna are available to the fishery. There were no significant differences in mean length of 15 species. Observers collected 76 straightened hooks, of which six were control and 70 were weak hooks. There was one observation of a FW released from a stronger circle hook. Overall, there was no statistical reduction in catch rates of bycatch species.
\end{abstract}

Various regulations on uses of bycatch reduction technologies (BRTs) have been enacted in the Hawaii-based longline fisheries to reduce the frequency and severity of incidental interactions with bycatch species such as seabirds and sea turtles. Longline fisheries based in Hawaii are composed of a deep-set fishery targeting bigeye tuna (Thunnus obesus, see Table 1 for species authorities) and a shallow-set fishery targeting swordfish (Xiphias gladius). Bycatch mitigation efforts have largely focused on the shallow-set fishery given higher interaction rates with seabirds, such as Laysan (Phoebastria immutabilis) and Black-footed Albatrosses (Phoebastria nigripes) and sea turtles, including loggerhead (Caretta caretta) and leatherbacks (Dermochelys coriacea, Gilman et al. 2007, 2008). Seabird mitigation measures were initially adopted in 2001 and subsequently amended in 2005. Measures included several options for fishers, such as: weighted branchlines, blue-dyed baits, strategic offal discards, bird curtains, side vs stern deployment of the longline, and mandatory night deployment and specific baits when targeting swordfish. Since 2004, the estimated total number of interactions with albatrosses hooked or entangled incidentally in Hawaii pelagic longline fisheries has been reduced by $92 \%-99 \%$ annually compared to year 2000 or preregulation estimates (NMFS 2010).

Stricter regulatory measures were enacted for the shallow-set fishery in 2004 due to concerns over sea turtle interactions. Measures mandated a switch from using J-hooks and squid bait to $18 / 0$ circle hooks with no more than a $10^{\circ}$ offset, whole fish 
bait, restricted annual effort, annual limits for the number of interactions with leatherback and loggerhead sea turtles, $100 \%$ observer coverage, and vessel possession and use of required mitigation gear (e.g., dehookers, dip nets; Gilman et al. 2007). In addition, renewal of fishing permits is contingent upon annual completion by vessel owners and operators of a NOAA NMFS-sponsored workshop on bycatch mitigation techniques (50 CFR 665 Subpart F). Following the introduction of these regulations, there have been significant reductions in catch rates for blue shark $(29 \%$, Walsh et al. 2009), loggerhead (90\%), and leatherback turtles (83\%), while swordfish catch rates significantly increased 16\% (Gilman et al. 2007). Despite the recent success of BRTs to reduce bycatch of seabirds and sea turtles in Hawaii's shallow-set fishery, recent concern focuses on interactions with marine mammals within the deep-set tuna sector, especially false killer whale (FKW, Pseudorca crassidens) and short-finned pilot whale (Globicephala macrorhynchus). Both species are vulnerable to hooking or entanglement while depredating longline bait or catch (Forney et al. 2011).

The United States Marine Mammal Protection Act (MMPA) requires estimation of annual mortalities and serious injuries of marine mammals that occur within US waters. Incidental mortality, serious injury, and non-serious injury of marine mammals in the Hawaii (McCracken and Forney 2010) and American Samoa longline fisheries are estimated from observer data. US longline fisheries based in Hawaii and American Samoa can potentially interact with four false killer whale management stocks as identified in a recent MMPA stock assessment report (Carretta 2010): (1) a Hawaii Insular stock of FKW within $40 \mathrm{~km}$ of the main Hawaiian Islands, (2) a Hawaii Pelagic stock of FKW beyond $140 \mathrm{~km}$ of the main Hawaiian Islands, (3) a stock of FKW within the Palmyra Atoll Exclusive Economic Zone (EEZ), and (4) a stock of FKW within the American Samoa EEZ. The Hawaii Insular and Pelagic stocks overlap between 40 and $140 \mathrm{~km}$ offshore of the main Hawaiian Islands.

From 2004 to 2008, the deep-set longline fishery interacted with 19 FKW from the Hawaii Pelagic stock based on $20 \%-26 \%$ observer coverage. Nine mortalities and serious injuries of pelagic FKW were documented in the deep-set fishery in the Hawaii EEZ, yielding a mean take estimate of 7.3 animals $\mathrm{yr}^{-1}$. During the same period, six serious injuries were documented in the fishery outside of the Hawaii EEZ, resulting in an additional estimated mortality and serious injury of 5.3 animals $\mathrm{yr}^{-1}$. From 2004 to 2008 , the shallow-set fishery with $100 \%$ observer coverage documented one hooked or entangled FKW which was not seriously injured. FKW interactions are rarer in the shallow-set fishery which operates at higher latitudes in cooler waters. The take rate for the Hawaii Pelagic stock exceeds the potential biological removal (PBR) level of $2.5 \mathrm{FKW} \mathrm{yr}^{-1}$, thus the population is considered "strategic" under the MMPA and takes must be reduced. Under the MMPA, a take reduction plan (TRP) was developed for the Hawaii-based deep and shallow-set fisheries to assist in the recovery and prevent depletion of the "strategic" Hawaii Pelagic stock. Recommendations consisted of potential changes to the terminal hooks in the longline gear, increased captain training on best practices for reducing marine mammal bycatch, handling and release techniques, and spatial management (closed areas). The paramount longline recommendation was to evaluate whether fishing with socalled "weak" circle hooks will affect the target catch of bigeye tuna and bycatch of FKW.

Operators in the Hawaii-based tuna sector have traditionally used Japanese-style tuna hooks, size 3.6 or 3.8 sun (hereafter referred as "tuna" hooks). Since 2005, 
several operators have voluntarily changed their terminal gear to circle hooks, typically ranging in size from $14 / 0$ to $16 / 0$, which are generally weaker and straighten with less force than tuna hooks. Hooks are fabricated by two methods: forging or bending a particular gauge of wire. "Weaker" hooks can be achieved by reducing the wire diameter. The use of weak hook technology has been investigated in several US pelagic longline fisheries to assess the potential for bycatch reduction while not significantly affecting target species catch rates. Weak hooks were tested in the yellowfin tuna (Thunnus albacares) and swordfish longline fisheries in the Mid-Atlantic and South Atlantic Bight, respectively, to evaluate their potential to reduce bycatch rates of pilot whales (Bayse and Kerstetter 2010). That study found no significant reduction in total retained catch between strong and weak 16/0 circle hooks in 21 sets targeting yellowfin tuna. Nine longline sets targeting swordfish with strong and weak 18/0 circle hooks had similar catches for all species except swordfish, which had statistically higher catch rates [catch per unit effort (CPUE, number per 1000 hooks)] and landed catches with strong hooks.

In the Gulf of Mexico, a major spawning area for the western Atlantic bluefin tuna (Thunnus thynnus) stock exists and weak hooks have been trialed in the Gulf of Mexico yellowfin longline fishery to determine whether they reduce unwanted mortality of the much larger bluefin (Foster and Bergmann 2010). From 2008 to 2010, relatively strong and weak 16/0 circle hooks were trialed on 311 longline sets $(198,606$ hooks). There were no significant CPUE differences for 20 of the 23 species analyzed, including target yellowfin tuna. Bluefin tuna catches were significantly reduced by $56.5 \%$ on weak hooks $(n=10)$ compared to stronger hooks $(n=23)$ and statistically lower CPUE was evident for lancetfish (14.8\%) and wahoo (26.6\%) on weaker hooks.

Because longline interactions with marine mammals are exceedingly rare, an unrealistically large number of longline sets (sample size) would be required to statistically demonstrate the efficacy of a BRT to reduce these rare marine mammal interactions. Under these circumstances, field trials testing BRTs are evaluated with regard to maintaining target species catch rates. The specific intentions of the present study were to quantify the effects of strong and weak circle hooks in the Hawaii-based deep-set fishery targeting bigeye tuna. Specifically, we documented the following with respect to hook strength category: (1) catch rates of target, incidental (retained non-target), and bycatch (discarded or released) species; (2) size selectivity; (3) frequency of straightened hooks; (4) historical hook use in the fishery from 2004 to 2010; and (5) an account of a FKW interaction.

\section{MAterials AND MethodS}

\section{Protocols}

Vessel.-A sample size was estimated based on a request in the draft TRP for sufficient trials to be conducted to statistically detect a $10 \%$ or greater reduction in the weight of bigeye tuna caught on weaker hooks compared to the catch on stronger hooks. A power analysis of historical bigeye catch rates in the deep-set fishery indicated that approximately 120 longline sets would be required to detect a $10 \%$ reduction in catch rate, assuming $\alpha=0.1$ and $\beta=0.2$. Four Hawaii-based tuna longline vessels were contracted between October and December 2010 to conduct the trials comparing control (stronger) and weaker circle hooks. The vessels used Korean-made circle hooks of size 15/0, stainless, and $10^{\circ}$ offset (Fig. 1). On all longline deployments, vessels sequentially alternated control circle hooks with a wire diameter of 4.5 $\mathrm{mm}$ with weaker circle hooks of $4.0 \mathrm{~mm}$ wire diameter. Strength tests were conducted using 

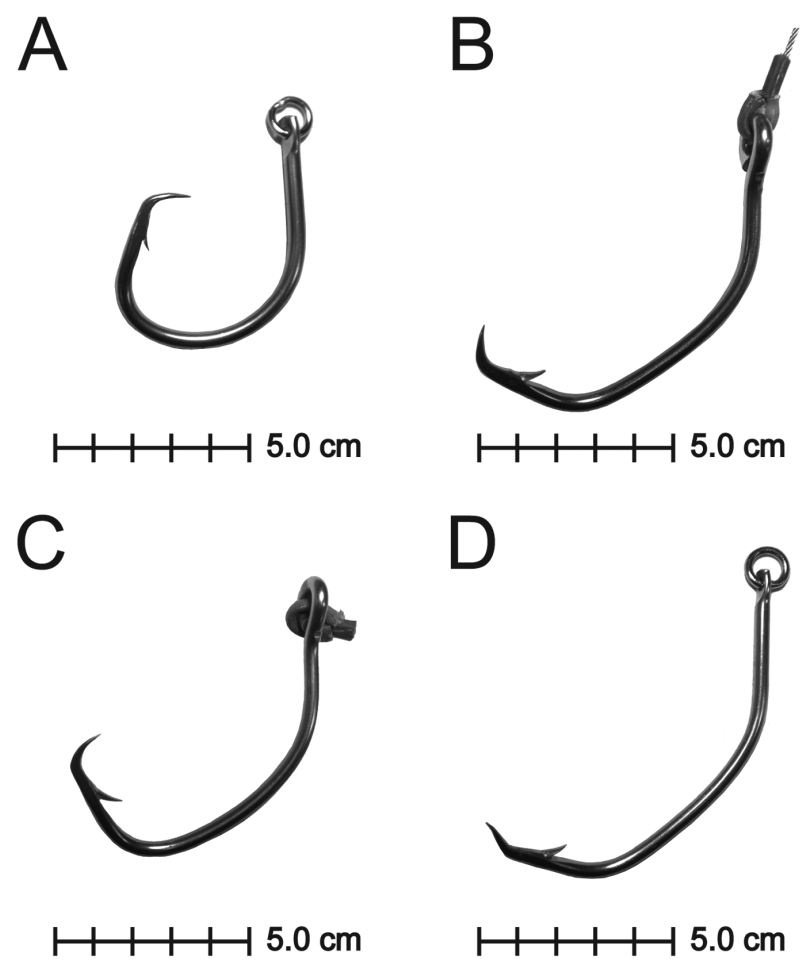

Figure 1. Examples of an unfished and straightened hooks during trials of 127 Hawaii-based tuna longline sets deploying control (strong) and weak circle hooks. (A) Lateral view of a unfished control 15/0 circle hook composed of $4.5 \mathrm{~mm}$ diameter wire used in the field trials. Circle hook dimensions (terminology from Curran and Bigelow 2011) were maximum length $=6.6 \mathrm{~cm}$, straight total length $=5.7 \mathrm{~cm}$, straight total width $=4.7 \mathrm{~cm}$, minimum width $=4.4 \mathrm{~cm}$, and gape $=2.5 \mathrm{~cm}$. (B) Control hook straightened by a false killer whale, (C) weak hook with a $131 \mathrm{~cm}$ FL retained bigeye tuna, and (D) a weak hook from an unknown animal.

a digital hydraulic hook/line tester to ascertain when the stronger control and weaker 15/0 circle hooks would straighten, which was defined as when a hook was deformed to a degree (hook gape of $3.9 \mathrm{~cm}$ or greater) to which fish or marine mammal escapement was likely. The control hook straightened at approximately $303 \mathrm{lbs}(137.7 \mathrm{kgs}, n=3$, range $300-310 \mathrm{lbs})$ of pull force and the weaker hook straightened at approximately $205 \mathrm{lbs}(93.2 \mathrm{kgs}, n=6$, range 196-214 lbs; J Hall, Hawaii Longline Association, unpubl data). Fishermen often have a preference for ringed or non-ringed hooks. Two vessels chose to deploy control and weak hooks with rings and the other two vessels chose to deploy non-ringed hooks. Throughout the field trials, all vessels were mandated to alternate hook types throughout the entire longline set and to maintain a 1:1 ratio of hook types throughout the trials. Branchline snaps marked with 10 -cm cable ties allowed for easy identification of the terminal hook type and corresponding fish catch. Vessel captains chose where they fished and were allowed to retain and sell their catch.

Observers.-Data were collected by personnel of the Pacific Islands Regional Observer Program. Observers collected information on all catch by species, hook type, sequential hook number of capture between two floats, caught condition (alive, dead), catch disposition (retained, discarded), length measurements of some landed species, tally of the numbers of each type of hook deployed and retrieved, and a vessel's ability to follow experimental protocols. 


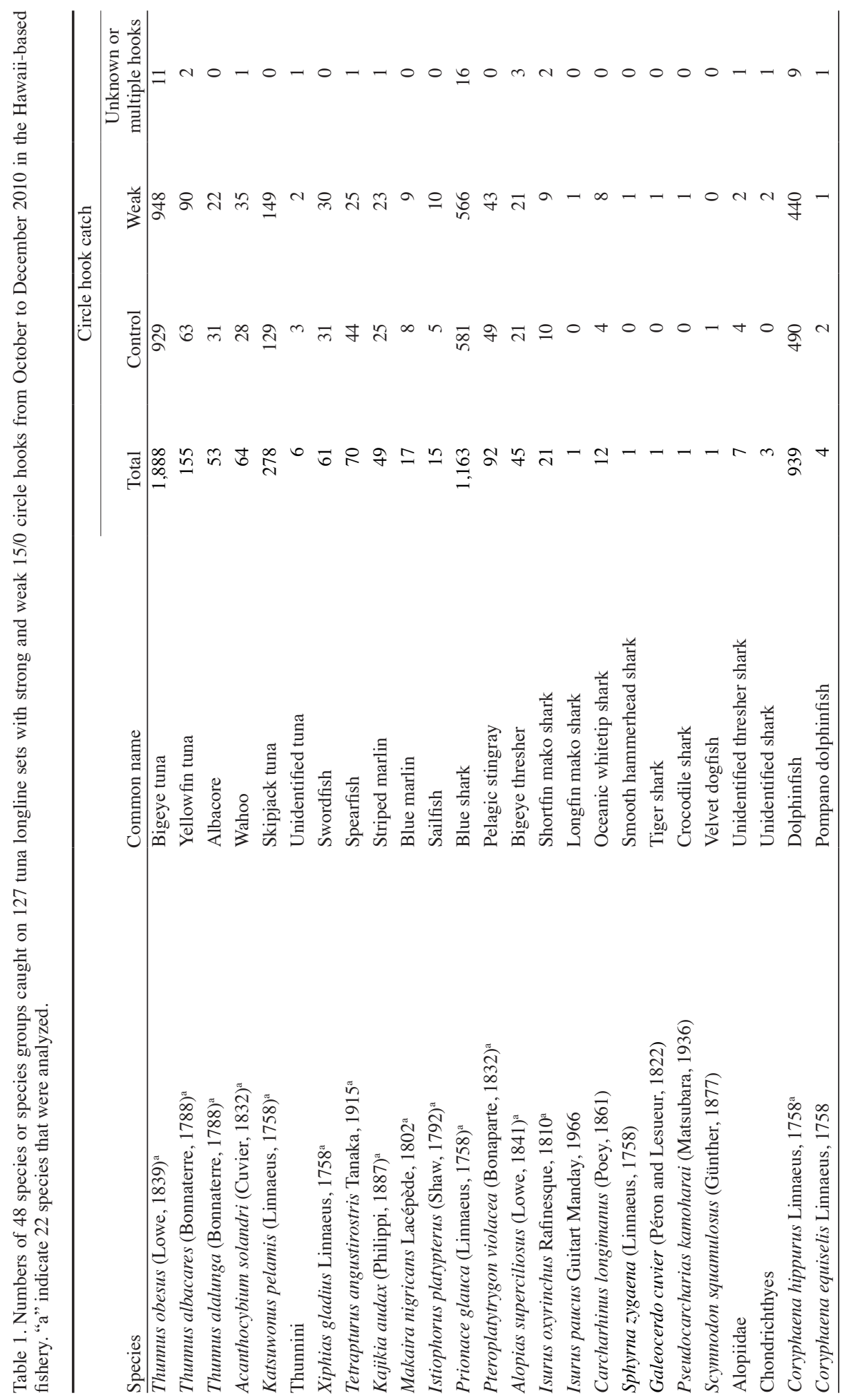




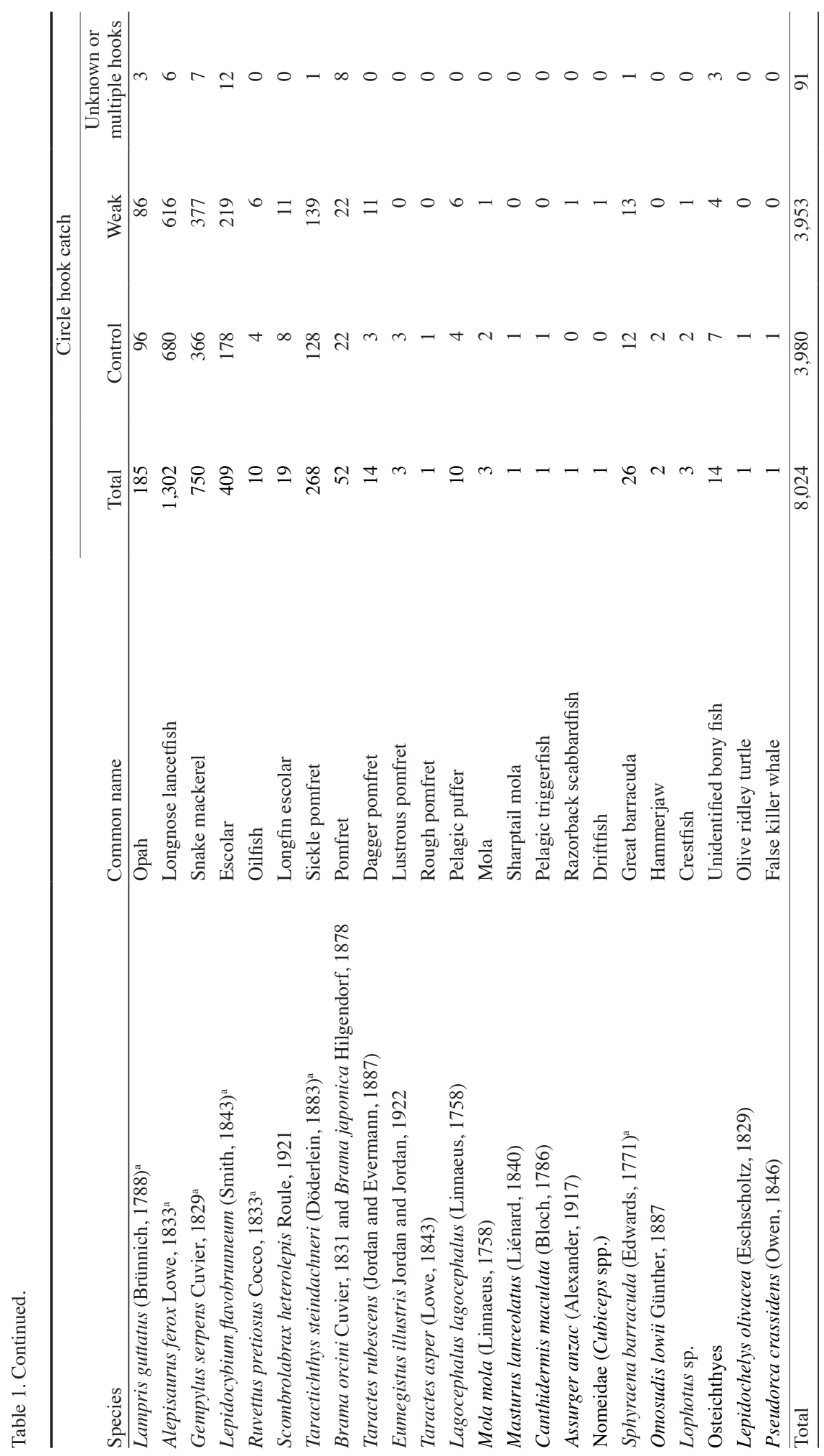


Hook type was recorded for each species caught. Observers measured eye-fork length (EFL) for billfishes and fork length (FL) for all other fishes that were brought aboard to the nearest whole centimeter. An approximate length to the nearest whole foot $(25.4 \mathrm{~cm})$ was recorded if the animal was not landed. Straightened hooks were retained by the observer, who recorded the sequential hook number, species, and size of fish if the fish was retained on the hook.

\section{ANALYSES}

Catch.-In total, 127 longline sets were analyzed and two sets were excluded from analysis for not complying with the protocol of deploying a minimum of 2000 hooks per set. Catch records of 91 fishes (1.12\%) were deleted due to uncertain hook type or if an animal was caught on multiple hooks. The most numerous 22 species were chosen for analysis (Table 1), the least numerous of which had a mean catch rate of 0.12 fish per set. Additional species were not considered due to their uncommon occurrence, grouping at higher taxa, or uncertain species identifications (Table 1).

A randomization test (Manly 2007) was used to assess catch differences between hook types. The null hypothesis was that there would be no difference in catch between paired hook types. The test statistic $(S)$ was the mean difference in catch between paired control circle hooks and weak circle hooks by set. A randomization test was written and conducted in the R statistical programming language (R Development Core Team 2008, version 2.7.2 for Linux). Data were randomized, resampled 10,000 times, and scored for whether or not the resampled $S$ value was equal to or greater than the observed $S$ value. This method provides a measure of the strength of evidence against a null hypothesis rather than estimating significance at a certain probability level. Fish lengths were transformed with natural logarithms and means were tested for hook type effects using one-way ANOVA.

Bigeye Tuna Length-Weight Relationship and Catch Rate in Weight.-Additional analyses were considered for target bigeye tuna as fishermen preferred analyses structured upon catch weight compared to catch numbers. A randomization test was used to assess differences in the bigeye tuna catches in weight between hook types for each longline set. Bigeye tuna weights were calculated from FL measurements obtained from observers. A length-weight relationship for bigeye tuna was updated from results of Nakamura and Uchiyama (1966) who analyzed 9144 fish caught in the central Pacific, part of a larger data set collected from 1960 to 1970 that included 11,649 length-weight measurements. A length-weight regression equation $\left(\mathrm{W}=a \mathrm{FL}^{b}\right)$ was estimated from logarithmically transformed data as $\log \mathrm{W}=\log a+b \log$ $\mathrm{FL}$, where $\mathrm{W}$ is weight (kgs), FL is fork length $(\mathrm{cm}), a$ is the regression intercept, and $b$ is the regression slope. Outliers were evident in a visual inspection of these data, and the regression was fit as a robust linear model $(r l m)$ function in the MASS library in R.

Weight estimates were not available for all bigeye tuna due to an observer missing a FL measurement or depredation occurring by sharks or marine mammals so that FL could not be measured. When bigeye FL measurements were not obtained, values were substituted according to two scenarios by using the mean FLs by each hook type calculated within a particular trip. In Scenario 1, the vessel's catch was calculated by substituting mean FLs for unmeasured individuals. In Scenario 2, the vessel's catch without depredation was estimated by substituting mean FLs for both unmeasured and depredated individuals.

Straightened Hooks.-Observers obtained and labeled any bent or straightened hooks that were discarded by the crew. Hooks were measured and compared to unfished control and weak 15/0 circle hooks. Hook deformation was characterized by hook measurements of maximum length, straight total length, straight total width, minimum width, and gape length following Curran and Bigelow (2011). Maximum length was measured from the top of the eye loop or ring to the farthest point of the hook, this being the bend or the point of the tip on the bite. Straight total length was measured from the eye to the lowest part of the hook when the shank was held vertically. Straight total width was measured from the shank to the farthest point horizontally when the shank was held vertically. Minimum width was measured as the 
smallest distance between parallel planes that would contain the entire hook. The hook gape was measured from the point of the tip $90^{\circ}$ to the hook shank. Gape measurements were not possible for some hooks that were straightened.

Hook Types Historically Used in the Deep-Set Fishery.-Historical hook use in the deep-set fishery was documented from observer data from 2004 to 2010 with corresponding annual coverage rates of $20 \%-26 \%$. For each longline set, observers recorded the predominant hook style, size, and whether the hook was offset or non-offset. Observers noted the approximate percentages of each hook style and size in the comments field of a particular trip record if a vessel fished with a mixture of styles or sizes. Hook styles and sizes were categorized on a trip basis as: "pure circle" for 14/0, 15/0, or 16/0 offset or non-offset circle hooks; "pure tuna" for tuna hooks of 3.6 or 3.8 sun; "other" for using 18/0 circle or J-hooks; and "mixed" for using more than one of the previous categories.

Temporal Variability in Landed Bigeye Size.-Individual bigeye tuna weights of longline landings were obtained from sales records of the United Fishing Agency, Ltd. (UFA). Mean monthly weight was estimated from 2005 to 2009 for bigeye tuna caught by the deep-set fishery. When bigeye tuna were processed prior to sale (e.g., headed and gutted, gilled and gutted), a conversion factor was applied to convert to whole weight. The distribution of bigeye tuna weights by month were viewed as empirical distribution plots (ecdf in R) and median and $75^{\text {th }}$ percentile weights were estimated by quantile regression ( $r q$ in $\left.\mathrm{R}\right)$.

\section{RESULTS}

\section{$\mathrm{CATCH}$}

Four fishing vessels conducted 10 trips in the vicinity of the Hawaiian Archipelago in an area bounded by $14^{\circ} \mathrm{N}-26^{\circ} \mathrm{N}$ and $143^{\circ} \mathrm{W}-167^{\circ} \mathrm{W}$ and deployed 127 longline sets with 302,738 hooks. Longline trials occurred from October 1 to December 18, 2010. Longline gear and operational characteristics in the trials (Table 2) were similar to previous descriptions of the Hawaii-based tuna sector (Bigelow et al. 2006, Curran and Bigelow 2011). Hook trials caught 8024 individual (ind) animals representing 48 species or species groups (Table 1). Twenty-two species had $>14$ ind captured, and these species represented $97.9 \%$ of the total catch by number. Numerically, bigeye tuna (1888 ind) were the most predominant catch, followed by longnose lancetfish (Alepisaurus ferox; 1302), blue shark (1163), and dolphinfish (Coryphaena hippurus; 939). Nominal CPUE (number of fish caught per 1000 hooks) of all 48 species captured was 26.29 for control and 26.11 for weaker circle hooks, and nominal CPUE of retained species was 13.75 for control and 13.81 for weaker hooks. Randomization tests detected no significant differences in CPUE between hook types for 20 species (Table 3, Fig. 2). There were significant differences for yellowfin tuna and spearfish (Table 3), but with opposite trends as yellowfin catches were higher on weaker hooks and spearfish catches were higher on control hooks. Relationships between hook type and fish lengths were tested for 15 species (Table 4, Figs. 3-4). The length analysis for 15 species represents a subset of the 22 species considered in the catch rate analysis, because shark species were not landed and, therefore, not measured. F-tests indicated no significant differences $(P>0.05$, Table 4$)$ between hook types in mean fish length, for all species. The largest bigeye tuna obtained by a control hook $[180 \mathrm{~cm}$ FL (approximately $128 \mathrm{~kg}$ )] was of similar size as the largest on a weak hook [177 cm FL (approximately $122 \mathrm{~kg}$ )]. The largest blue marlin obtained by a control hook was 228 cm EFL with an estimated weight of $166.5 \mathrm{~kg}$ (Uchiyama and Kazama 2003); a similar sized blue marlin (223 cm EFL, $154.3 \mathrm{~kg}$ ) was landed with a straightened weak hook. 
The trials caught one FKW (see False Killer Whale Interaction below) and one olive ridley turtle (65 cm carapace length). The turtle was hooked with a control hook in the front flipper on the $7^{\text {th }}$ hook from the floatline (i.e., hook number 19 while fishing with 25 hooks between floats). The turtle had little response when brought aboard and was pronounced dead after a $22-\mathrm{hr}$ period of attempted resuscitation and monitoring.

Table 2. Mean $( \pm \mathrm{SD})$ for attributes of 127 tuna longline sets monitored with control (strong) and weak 15/0 circle hooks from October to December 2010 in the Hawaii-based fishery.

\begin{tabular}{lc}
\hline Variable & Mean \pm SD \\
\hline Begin deployment time (hrs) & $0725 \pm 0054$ \\
End deployment time (hrs) & $1225 \pm 0103$ \\
Begin haul time (hrs) & $1649 \pm 0105$ \\
End haul time (hrs) & $0412 \pm 0205$ \\
Hooks per set & $2384 \pm 155$ \\
Hooks between floats & $25.70 \pm 4.16$ \\
Floatline (m) & $23.7 \pm 2.6$ \\
Branchline + leader (m) & $12.2 \pm 1.2$ \\
Leader material & $47.7 \pm 4.7$ \\
Dropper weight size $(\mathrm{g})$ & 100\% sauries (Cololabis saira) \\
Bait & \\
\hline
\end{tabular}

Table 3. Statistical comparison from randomization tests of catch on control (strong) and weak circle hooks for 22 species caught on 127 tuna longline sets from October to December 2010 in the Hawaii-based fishery. Asterisk indicates significant difference in catch $(P<0.05)$.

\begin{tabular}{ll}
\hline Species & $P$-value \\
\hline Bigeye tuna number & 0.684 \\
Bigeye tuna weight & 0.513 \\
Yellowfin tuna & $0.038^{*}$ \\
Albacore & 0.281 \\
Wahoo & 0.406 \\
Skipjack tuna & 0.252 \\
Swordfish & 1.000 \\
Spearfish & $0.016^{*}$ \\
Striped marlin & 0.888 \\
Blue marlin & 1.000 \\
Sailfish & 0.231 \\
Blue shark & 0.671 \\
Pelagic stingray & 0.655 \\
Bigeye thresher & 1.000 \\
Shortfin mako & 1.000 \\
Dolphinfish & 0.091 \\
Opah & 0.484 \\
Longnose lancetfish & 0.117 \\
Snake mackerel & 0.711 \\
Escolar & 0.053 \\
Longfin escolar & 0.601 \\
Sickle pomfret & 0.551 \\
Barracuda & 1.000
\end{tabular}



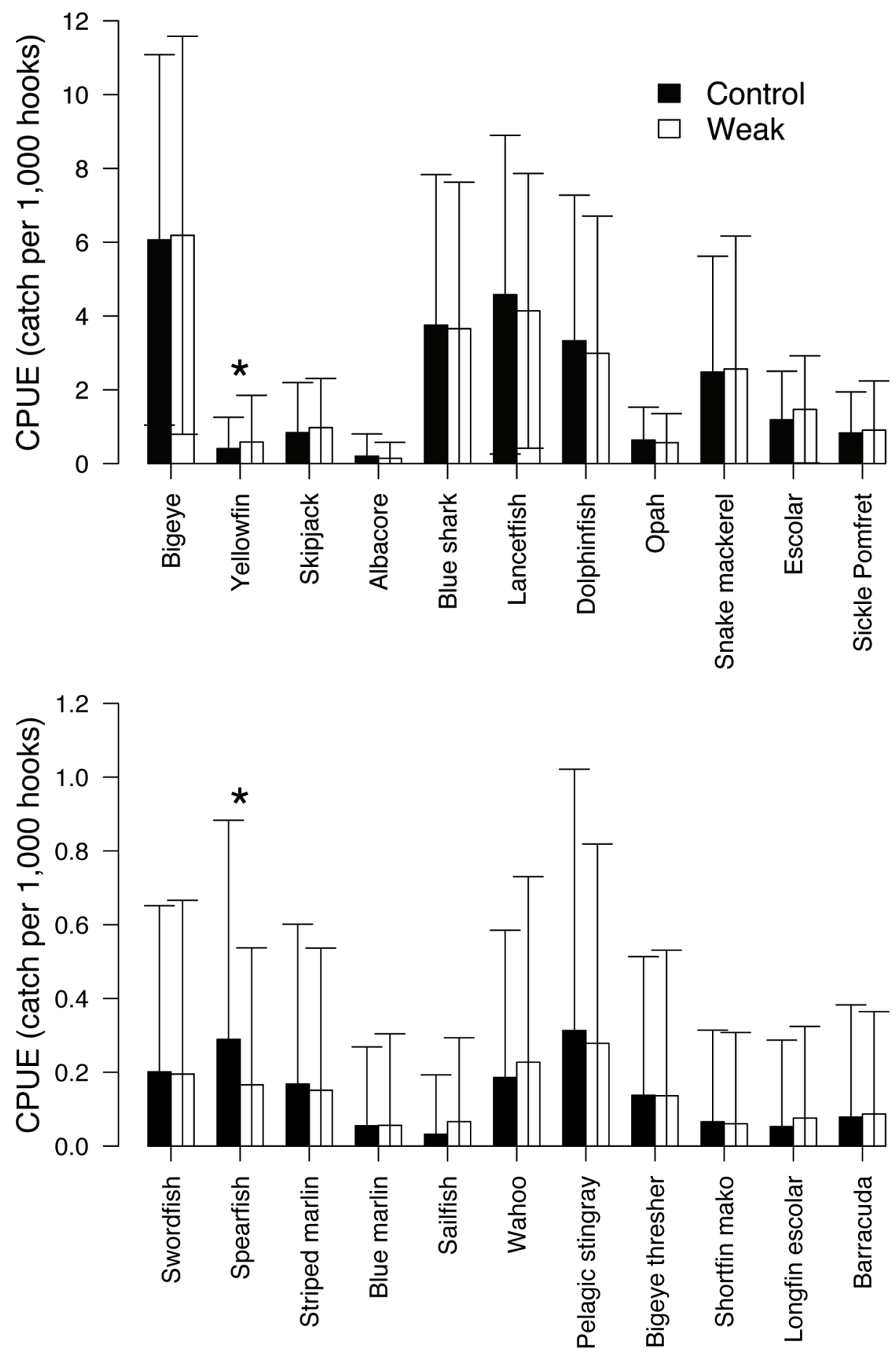

Figure 2. Comparison of mean catch per unit effort (CPUE, number per 1000 hooks) for 22 species captured from 127 Hawaii-based tuna longline sets deploying control (4.5 mm diameter wire) and weak $(4.0 \mathrm{~mm}$ diameter wire) circle hooks. Vertical bars indicate $+/$ - one standard deviation and asterisk indicates statistically significant differences in CPUE. 


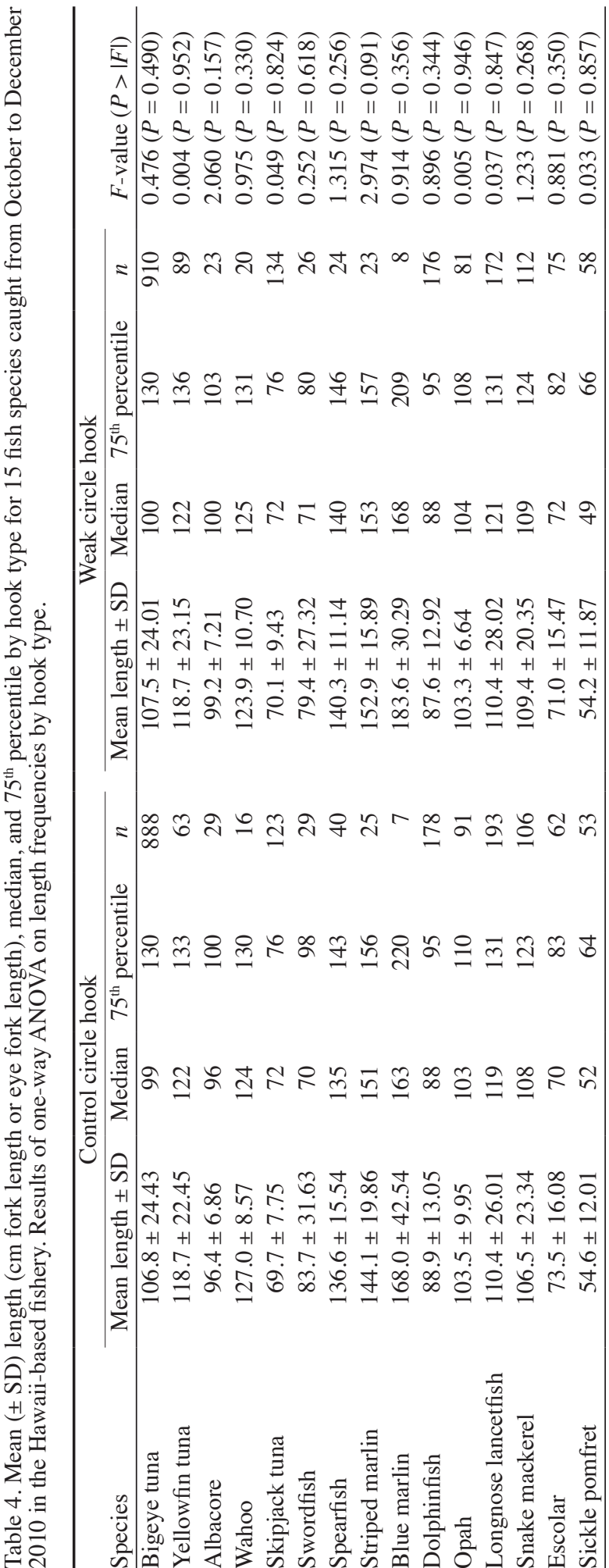



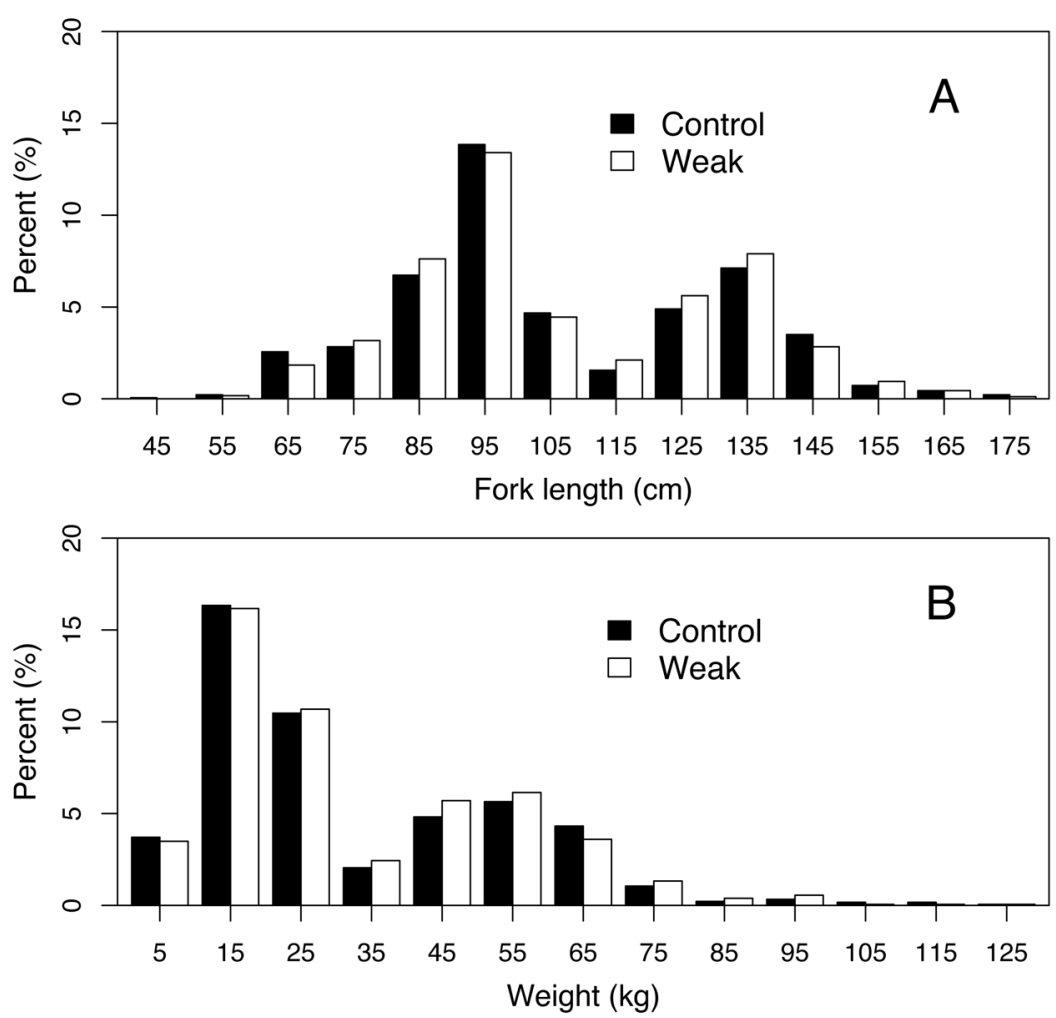

Figure 3. Comparison of bigeye tuna size [(A) fork length $(\mathrm{cm})$; (B) estimated whole weight $(\mathrm{kg})]$ captured from 127 Hawaii-based tuna longline sets deploying control and weak circle hooks.

\section{Bigeye Tuna Length-Weight Relationship and Catch}

The bigeye tuna length-weight regression was based on 11,579 observations, as 70 outliers were identified by the $r l m$. The estimated regression equation $\mathrm{W}=3.5146 \times$ $10^{-5} \mathrm{FL}^{2.9096}\left(65.4-193.0 \mathrm{~cm}\right.$ FL, $\left.R^{2}=0.974\right)$ was very similar to the regression computed by Nakamura and Uchiyama (1966) over the subset of data with a somewhat narrower length range (W $=3.6562 \times 10^{-5} \mathrm{FL}^{2.9018}, 80-190.0 \mathrm{~cm} \mathrm{FL}$ ).

There were no significant differences in bigeye tuna catch per set expressed in number of individuals or weight estimated from fork lengths (Table 3). The estimated total capture weight of bigeye tuna was higher for weaker hooks $(29,872 \mathrm{~kg}$; Table $5)$ than control hooks $(28,733 \mathrm{~kg})$. Depredation by marine mammals and sharks resulted in a $3 \%$ loss of bigeye tuna.

\section{Straightened Hooks}

Observers collected 76 straightened hooks (38 ringed and 38 non-ringed), of which six were control (three ringed and three non-ringed) and 70 were weak hooks (35 ringed and 35 non-ringed). Weak hooks had a significantly higher rate of straightening (Pearson's $X^{2}=53.895, P<0.0001$ ). There was no catch associated with 48 straightened (four control and 44 weak) hooks. Straightened weak hooks retained 21 bigeye tuna $($ mean $=148.1 \mathrm{~cm} \mathrm{FL}, \mathrm{SD}=13.72$, range $=131-175 \mathrm{~cm}, n=18$ ), four blue marlin $($ mean $=188.0 \mathrm{~cm} \mathrm{FL}, \mathrm{SD}=41.61$, range $=142-223 \mathrm{~cm}, n=3)$, one yellowfin tuna (140 cm FL), and one bigeye thresher shark [approximate length of $7 \mathrm{ft}$ 

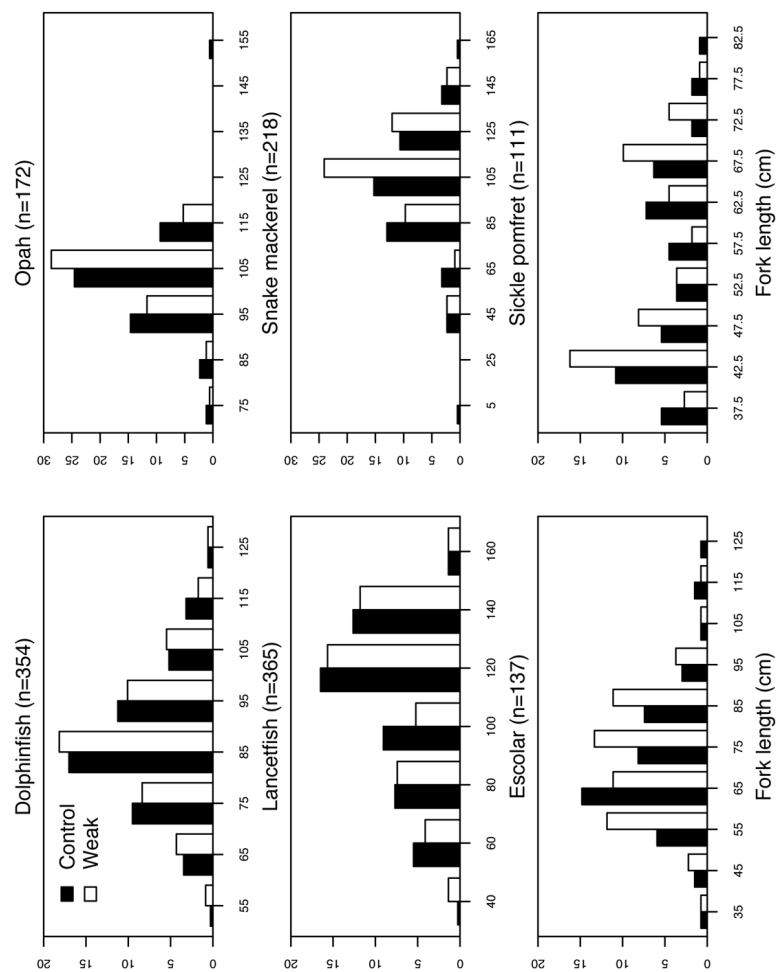

(\%) tuəכа丿d

(\%) ұนəכגəd

(\%) ұuəวıәd
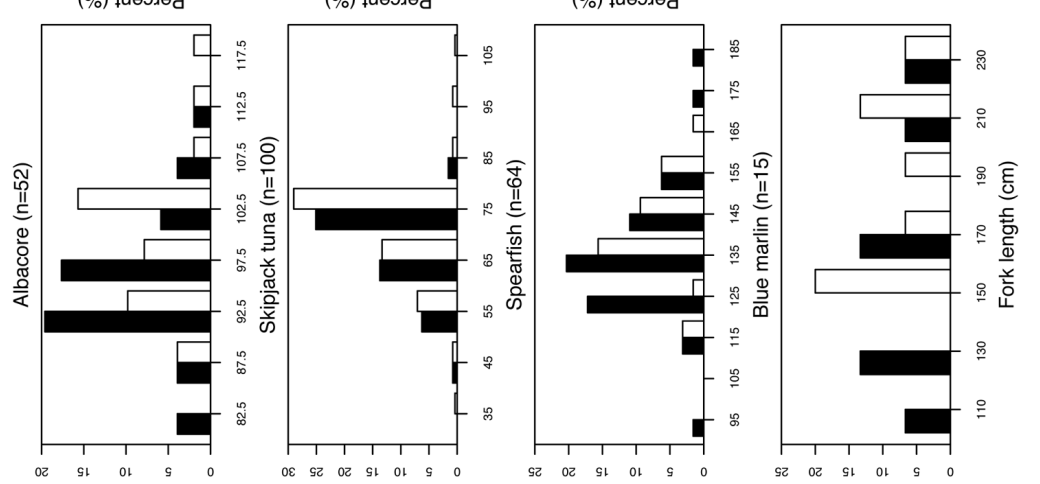

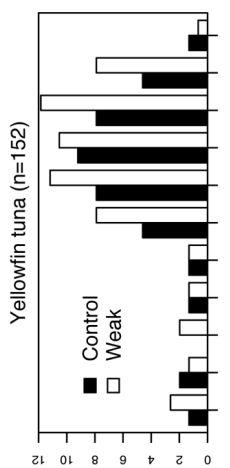

(\%) ұนәэәә

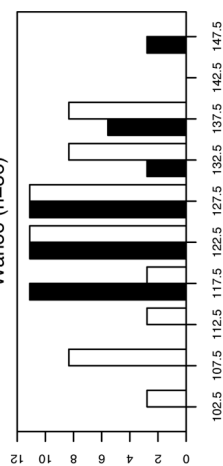

(\%) ұиәэәәd

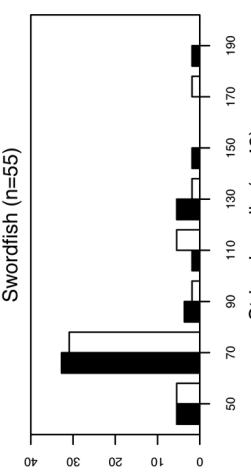

(\%) ңиәэдә्d

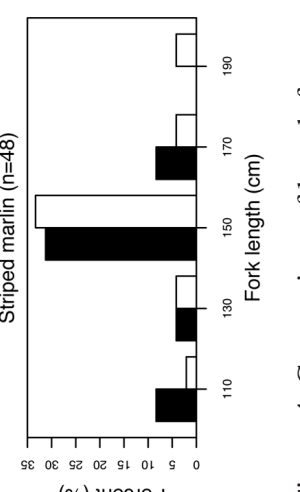

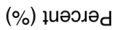


Table 5. Summary statistics by hook type for bigeye tuna for catch rate in number and weight from October to December 2010 for (A) control and weak hooks, and (B) both hook types in the Hawaiibased tuna fishery. Standard deviation is in parentheses.

\begin{tabular}{lcc}
\hline A & Control & Weak \\
\hline Catch (number) per 1000 hooks & $6.1(5.02)$ & $6.2(5.39)$ \\
Catch $(\mathrm{kg})$ per 1000 hooks & $187.1(152.08)$ & $194.6(159.37)$ \\
Catch $(\mathrm{kg})$ per 1000 hooks estimated without depredation & $194.0(158.98)$ & $200.6(162.59)$ \\
Total catch in weight $(\mathrm{kg})$ & 28,733 & 29,872 \\
Total catch in weight $(\mathrm{kg})$ estimated without depredation & 29,801 & 30,800 \\
Percentage $(\%)$ retained & 94.7 & 95.0 \\
\hline B & Both hook types \\
\hline Mean weight $(\mathrm{kg})$ and $75^{\text {th }}$ percentile, October-December & $32.4(20.94), 49.7$ \\
Mean weight $(\mathrm{kg})$ and $75^{\text {th }}$ percentile, October & $33.0(18.85), 47.5$ \\
Mean weight $(\mathrm{kg})$ and $75^{\text {th }}$ percentile, November & $32.7(21.20), 49.7$ \\
Mean weight $(\mathrm{kg})$ and $75^{\text {th }}$ percentile, December & $29.9(24.33), 51.9$ \\
\hline
\end{tabular}

(approximately $213 \mathrm{~cm})]$. One bigeye tuna $(173 \mathrm{~cm} \mathrm{FL}$ ) was retained on a straightened control hook. The magnitude of deformation was estimated from the gape size in relation to a $2.5 \mathrm{~cm}$ gape of a non-deformed hook. The gape of a control hook opened a mean of $65.6 \%$ (gape $=4.14 \mathrm{~cm}, \mathrm{SD}=0.71, n=5)$ while a weak hook opened a mean of $50.4 \%$ (gape $=3.76 \mathrm{~cm}, \mathrm{SD}=0.57, n=53$ ). A significant negative relationship $(P=$ $0.003, R^{2}=0.44$ ) was evident between fish size and hook gape for the 18 bigeye that were retained on straightened hooks for which FL measurements were obtained. A $131 \mathrm{~cm}$ (approximately $50 \mathrm{~kg}$ ) fish had the greatest hook deformation $(4.7 \mathrm{~cm}$ gape width) and a $175 \mathrm{~cm}$ (approximately $118 \mathrm{~kg}$ ) fish had the least hook deformation (2.9 cm gape width; Fig. 5).

\section{FALSE Killer Whale Interaction}

An observer documented the hooking and straightening of a control 15/0 circle hook (Fig. 1) by an approximately $4.3 \mathrm{~m}$ (approximately $14 \mathrm{ft}$ ) FKW on October 22, 2010. During longline retrieval, the observer noticed several FKW surfacing 1-2 m from the port side of the vessel. A whale dove toward a bait on a branchline that had been removed from the mainline and attached to a running line, which hangs from the vessel untended; removed branchlines are held on the running line prior to coiling. The branchline rapidly tightened and moved to the stern where the line slacked and the gear was retrieved by the observer. No injuries to the FKW were observed and no gear was entangled or retained on the whale. The interaction lasted a few minutes with the whale displaying typical, non-agitated behavior when swimming away upon release. The observer reported that the exact hooking location was unknown, but believed that the whale was hooked in the mouth. The length of the whale probably corresponds to a weight of $1100-1200 \mathrm{~kg}$, as the maximum size of a FKW is approximately $6.1 \mathrm{~m}$ and approximately $1400 \mathrm{~kg}$ (Leatherwood and Reeves 1983).

\section{Hook Types Historically Used in the DeEp-Set Fishery}

The use of tuna hooks in the deep-set tuna longline fishery declined precipitously from $87 \%$ in 2004 to $25 \%$ in 2010 , while circle hooks ranging in size from $14 / 0$ to $16 / 0$ increased from $5 \%$ to $43 \%$ (Fig. 6). The proliferation of the pure circle and mixed hook categories in 2006 suggests that tuna hooks may be entirely replaced in some vessels, while other vessels incrementally replace tuna hooks with circle hooks when gear is lost. The use of $18 / 0$ circle or J-hooks appears to be minimal $(0 \%-6 \%)$ in the deep-set fishery. 


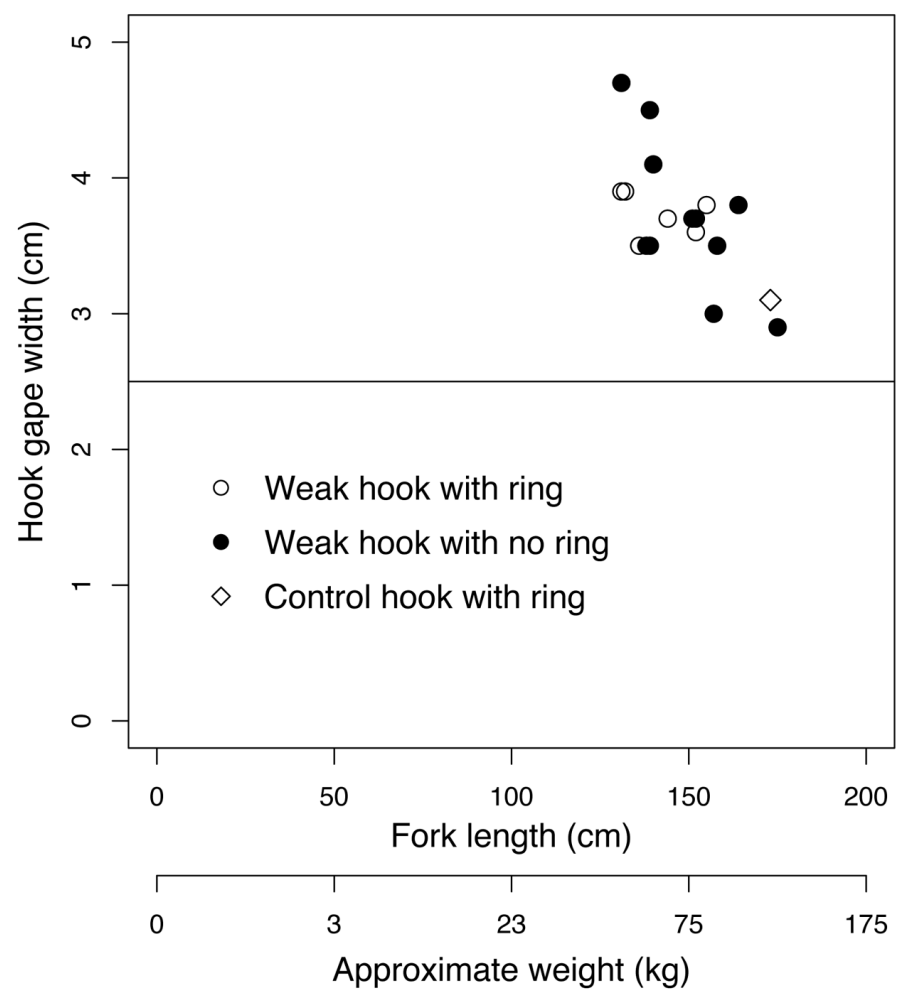

Figure 5. Relationship between circle hook gape width and bigeye tuna size for straightened control $(n=1)$ and weak $(n=17)$ circle hooks that retained bigeye tuna from October to December 2010 in the Hawaii-based tuna longline fishery. Horizontal line at $2.5 \mathrm{~cm}$ is the gape width of an unfished hook.

\section{Temporal Variability in Landed Bigeye Size}

Bigeye tuna landed in the deep-set tuna longline fishery exhibit moderate temporal variation in size (Fig. 7). Monthly mean weight of bigeye tuna landed from 2005 to 2009 ranged from a low of $34.1 \mathrm{~kg}$ in January to a high of $43.9 \mathrm{~kg}$ in June. Bigeye tuna landed during October-December ranged from 36.8 to $38.4 \mathrm{~kg}$ or averaged approximately $6 \mathrm{~kg}$ less than in June. Monthly patterns for larger bigeye ( $\left(75^{\text {th }}\right.$ percentile) followed the mean weights. The $75^{\text {th }}$ percentile of bigeye tuna landed from 2005 to 2009 ranged from a low of $43.8 \mathrm{~kg}$ in January to a high of $55.9 \mathrm{~kg}$ in May (Fig. 7). The $75^{\text {th }}$ percentile of bigeye tuna landed during October-December ranged from 48.0 to $51.2 \mathrm{~kg}$ or approximately $5 \mathrm{~kg}$ less than in May. Individual bigeye caught during the longline trials were not weighed; rather, weights of each fish were estimated from the length-weight relationship. The monthly mean estimated weight of bigeye tuna from the longline trials was $32.4 \mathrm{~kg}$ (range $=29.9-33.0 \mathrm{~kg}$, Table 5 ), approximately $5 \mathrm{~kg}$ less than October-December (2005-2009) means and approximately $11 \mathrm{~kg}$ less than bigeye typically landed in June (c.f. Tables 4 and Fig. 7). The monthly proportion of large bigeye $(>50 \mathrm{~kg}$ ) landed was similar to the mean weight trends. Large bigeye comprised the largest proportion of the catch $(28.2 \%-33.6 \%)$ during April to June and a smaller proportion $(22.0 \%-26.3 \%)$ during the circle hook trials. If bigeye escape on weaker hooks at hypothetical sizes of $>50 \mathrm{~kg}$, then the differential effects on catch rates between strong and weak circle hooks would be expected to be greater during spring when larger bigeye are more available to the fishery. 


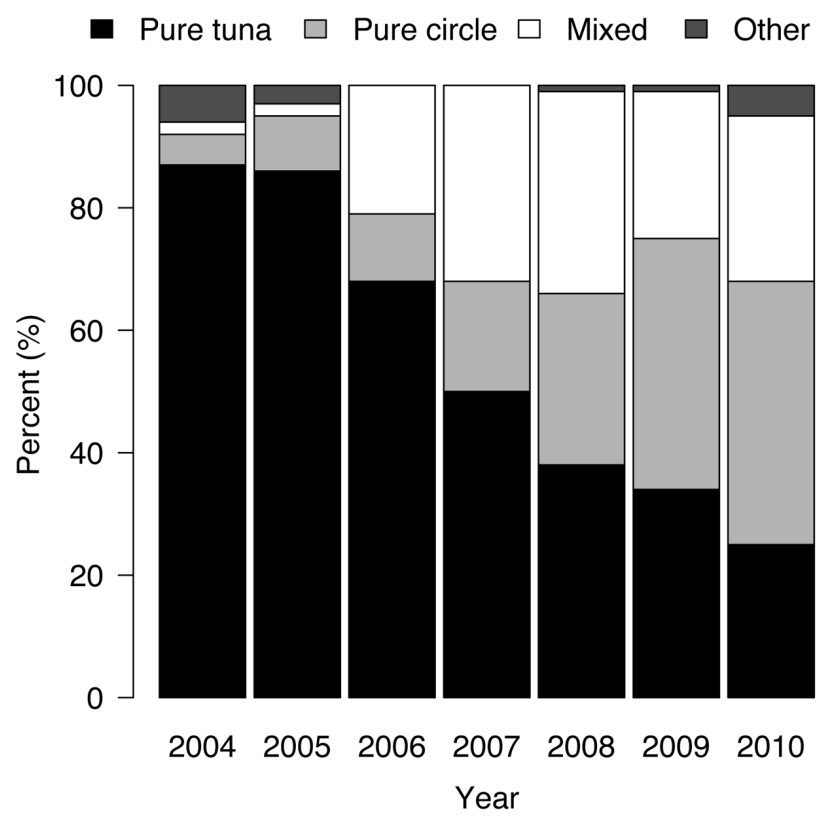

Figure 6. Annual composition of hooks used in the Hawaii-based tuna longline fishery. "Pure circle" is 14/0,15/0, or 16/0 offset or non-offset circle hooks; "Pure tuna" indicates tuna hooks of 3.6 or 3.8 sun; "Other" indicates 18/0 circle or J-hooks; and "Mixed" is more than one of the previous categories.

\section{Discussion}

Management agencies within the US have implemented BRTs, such as hook and/ or bait requirements to reduce the incidental capture and mortality of non-target species, especially for sea turtles in shallow-set pelagic fisheries targeting swordfish or yellowfin tuna. Shallow-set fisheries in the Pacific are required to use 18/0 circle hooks or larger with whole fish bait. In the Atlantic Northeast Distant Waters, 18/0 circle hooks are required with either whole Atlantic mackerel or squid bait (50 CFR 635.21). In the rest of the Atlantic and Gulf of Mexico waters, 18/0 or larger circle hooks with an offset not to exceed $10^{\circ}$ or $16 / 0$ or larger non-offset circle hooks are required with whole fish or squid bait. The relatively large (18/0) circle hooks aim to reduce the rate of ingestion and deep-hooking in sea turtles compared to tuna or J-hooks. While the benefits of using circle hooks and whole fish baits has been demonstrated for sea turtles (Watson et al. 2005, Gilman et al. 2007, Sales et al. 2010), their use has not been shown to reduce bycatch of marine mammals and large fishes. For these species, alternative BRT approaches, such as weak hook technology, may be required.

Longline gear has several components, and expectations in using weak hook technology are to make the hook the weakest component of terminal tackle. Use of the weaker hooks can exploit the size disparity between target and other species to promote the release of larger non-target species. As in other studies, our longline trials sequentially alternated control and weak hooks to investigate catch rates of target, incidental, and bycatch species (Watson et al. 2005, Kerstetter and Graves 2006, Bayse and Kerstetter 2010, Curran and Bigelow 2011). Alternating hooks worked well 

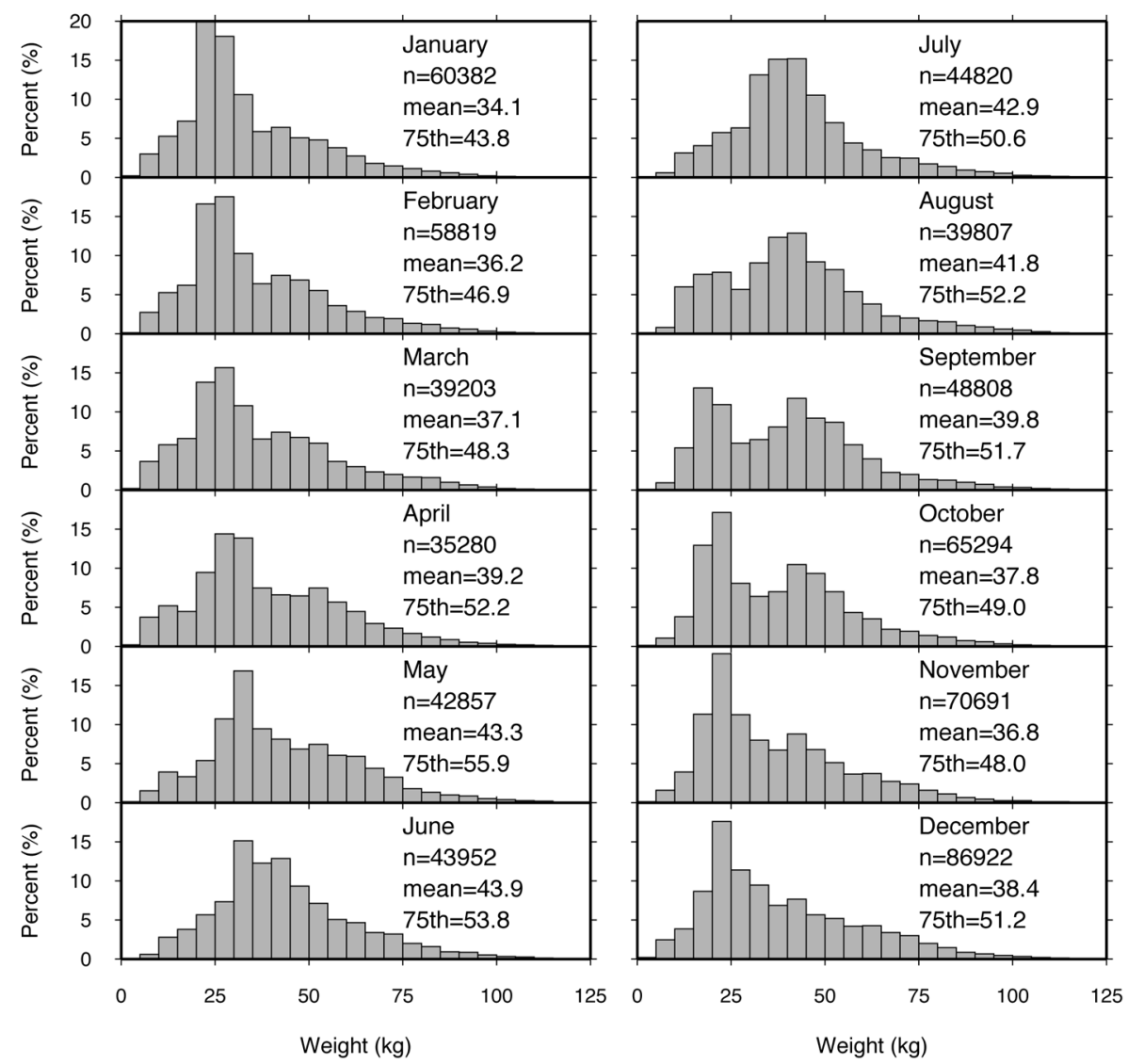

Figure 7. Monthly weight of bigeye tuna landed by the Hawaii-based tuna longline fishery and marketed at the United Fishing Agency, Ltd., from 2005 to 2009.

operationally and ensured that any effects of depth or habitat on a species' vulnerability to the longline or effects of spatial patchiness along the length of the longline were the same for both hook types.

Results indicated no significant differences among 15/0 control and weak hooks in target bigeye tuna size and catch rate (number and weight) per longline set. Nonsignificant differences in catch rate and size selectivity can result from at least two processes: (1) an inadequate sample size to rigorously test the null hypothesis of equality in catch rate and selectivity and (2) large individuals of a particular species not escaping from weaker hooks at a significantly higher rate than control hooks. Bigeye tuna were the most commonly caught animal in our study, and a sample size of 127 longline sets provided sufficient statistical power to test the hypothesis that catch rate or size selectivity were equal. The largest weak hook trial was conducted in the Gulf of Mexico where 311 sets were used to study mitigation of Atlantic bluefin bycatch (Foster and Bergmann 2010). Bluefin catch rates are low and the relatively large sample size was required to demonstrate that catches were significantly reduced by $56.5 \%$ (95\% CI $=8.7-79.3)$ on $16 / 0$ weak circle hooks $(n=10)$ compared to stronger $16 / 0$ hooks $(n=23)$. Relatively low sample sizes and resulting statistical power may have been an issue in the interpretation of results from weak hook trials 
in the western Atlantic yellowfin tuna and swordfish longline fisheries (Bayse and Kerstetter 2010). There was no significant difference in yellowfin tuna catch rates on 21 sets testing 16/0 strong and weak hooks, but yellowfin tuna caught on strong hooks had a mean length that was significantly greater than yellowfin caught by weaker hooks. A significantly higher number of swordfish were caught with strong 18/0 circle hooks compared to weak hooks, but individual swordfish were significantly heavier on weaker hooks.

The expectation of weak hooks is to reduce catches of species with relatively large mass; however, significant increases and decreases in catches have been demonstrated with weak hooks for species with relatively small or moderate mass. Yellowfin catches in the present study were significantly higher on weak hooks, which is contrary to expectations as larger yellowfin should have been of sufficient mass to deform weak hooks. The significant result for yellowfin may have been influenced by sample size $(n=153)$. Significantly higher catches on stronger hooks have been demonstrated for species of small mass such as spearfish (present study), lancetfish (Alepisauridae, Foster and Bergmann 2010), and pelagic stingray (Bayse and Kerstetter 2010). These small species would not be expected to have differing catch rates between strong and weak hooks of the same size. One could postulate that the higher catch rates may result from differing patterns of feeding behavior, though results are not consistent among studies as there were non-significant catch differences for lancetfish and pelagic stingray in our study.

Weak hooks in the present study were straightened more frequently than control hooks, though the rate of straightening was relatively low. Overall there was a 11.7:1 ratio of straightened weak to control hooks and a 11:1 ratio when straightened hooks had no catch. The overall weak hook straightening rate was 0.475 per 1000 hooks and 0.291 with no catch (Table 6). Seven weak hooks were retrieved straightened in the 16/0 trials in the western Atlantic, and observers retrieved 63 strong and 287 weak hooks that had been straightened to a degree that the animal escaped in the Gulf of Mexico trials. The straightening rate of 0.291 per 1000 weak hooks in our study is much lower than the rate of 2.890 for weak hooks in the Gulf of Mexico (Foster and Bergmann 2010) and lower than the yellowfin tuna weak hook experiment (0.439) in the western Atlantic (Bayse and Kerstetter 2010).

There were 48 straightened hooks without catch and five species (bigeye and yellowfin tuna, blue marlin, bigeye thresher shark, and FKW) demonstrated an ability to straighten at least 28 hooks. Additional species attaining a large size, such as mako sharks and other marine mammals, may also have straightened hooks. Bigeye tuna may have contributed to the straightening of hooks that did not retain catch, as bigeye had the highest catch rates during the trials, 21 bigeye were caught on straightened control $(n=1)$ and weak $(n=20)$ hooks, and based on hook number of capture (position between floats), the straightened hooks fished at intermediate and deep depths where bigeye are typically caught (Suzuki et al. 1977, Bigelow and Maunder 2007). Observers documented the species and animal size retained by straightened hooks. The significant negative relationship between hook deformation and bigeye tuna size was unexpected as larger fish are hypothesized to have a greater ability to deform hooks than smaller fish. While these data may indicate the minimum size at which a particular species can straighten a hook, there are no experimental nor theoretical data on what force within the water is required to deform hooks, as pull strength does not equate to animal size. Furthermore, the most important aspects 


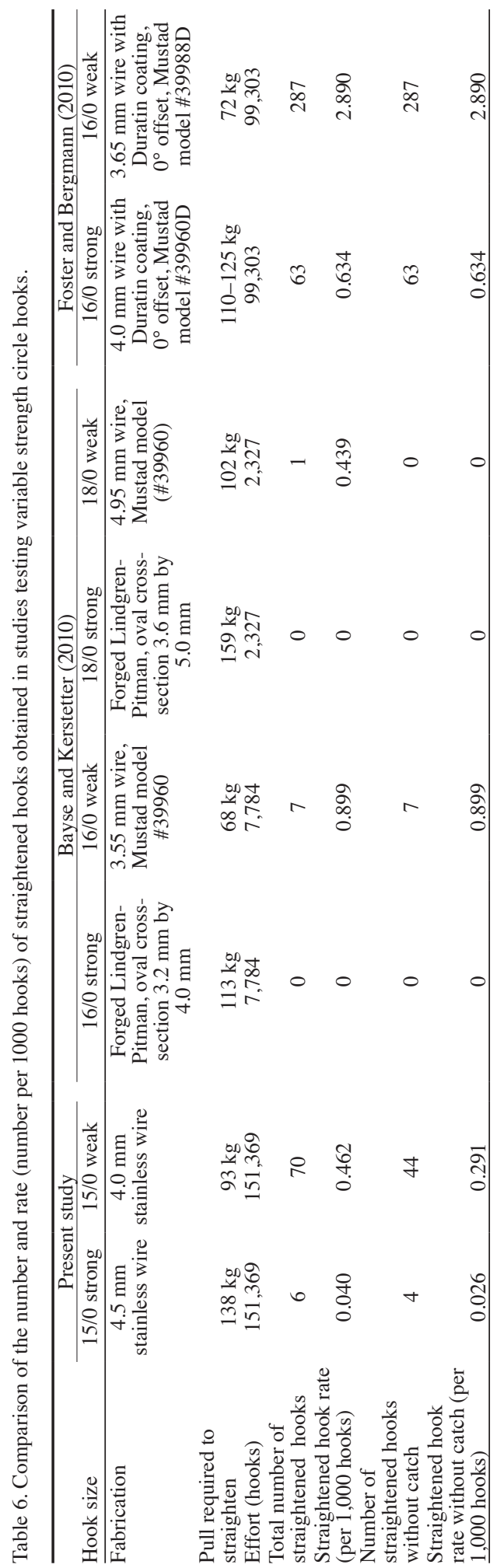


in hook deformation in longline fisheries are likely the direction and force of pull, which is affected by hook attachment to the branchline (e.g., ring vs non-ring), hooking location on the animal, and force applied to the mainline and branchline upon longline retrieval.

Statistical results on target bigeye catch rate and selectivity indicated no significant differences between hook types; however, there may be limitations to these statistical inferences because longline trials were not conducted when larger bigeye tuna are available to the deep-set fishery and a large portion of the fishing area was closed during $1 \mathrm{mo}$ of the trials. The trials were conducted over a period of $2.5 \mathrm{mo}$, a time frame predicated by fishery managers who anticipated that regulations for marine mammal bycatch reduction, possibly including requirements for circle hooks, would have to be formulated by March 2011. The mean weight of bigeye tuna caught during the October-December longline trials was $32.4 \mathrm{~kg}$. Mean monthly weights were approximately $5 \mathrm{~kg}$ less than historical October-December (2005-2009) means and approximately $11 \mathrm{~kg}$ less than June (2005-2009). While we cannot postulate if similar results would have been obtained if trials were conducted when bigeye of a larger mean size were available to the fishery, the temporal variability in bigeye size in the deep-set fishery depends on several factors such as: (1) spatial distribution of the fleet, (2) migration of age classes, (3) gear depth, as deeper gear catches larger bigeye because there is an ontogenetic change in habitat and depth, and (4) oceanographic effects operating on a variety of scales.

Smaller bigeye tuna captured during trials in December probably result from a shift in fishing to the eastern Pacific Ocean because of Regional Fisheries Management Organization (RFMO) regulations. The US pelagic longline fisheries in the Pacific are regulated by two tuna-RFMOs: the Western and Central Pacific Fisheries Commission (WCPFC) and the Inter-American Tropical Tuna Commission (IATTC). Jurisdictional separation of the two Commissions occurs to the east of the Hawaiian Archipelago at $150^{\circ} \mathrm{W}$. The US is subject to an annual longline catch limit for bigeye tuna in both Commission regulatory areas. The WCPFC area was closed to most of the Hawaii-based deep-set fleet from November 22 to December 31, 2010, because NMFS determined that the longline fleet would likely reach its annual bigeye catch limit on November 22. Vessels moved into the IATTC area, where smaller bigeye occur during December $($ mean $=29.9 \mathrm{~kg}$ ). The bimodal length structure of bigeye catch in the present study contained modes at 95 and $135 \mathrm{~cm}$, corresponding to ages of 2.5 and 4.5 yrs, respectively (Harley et al. 2010). The temporal variability in size may largely be determined by bigeye migration of different age classes, though such immigration and emigration to the Hawaii-based fishery are not well understood.

In the absence of fishery regulations, there has been a voluntary progression from using strong to weaker hooks in the Hawaii-based deep-set fishery. Tuna hooks were the dominant hook in the fishery prior to 2007. These hooks require substantially greater force to straighten in comparison to circle hooks and have a higher frequency of deep hooking vs mouth hooking for sea turtles and marlins, which may increase post-release mortality (Watson et al. 2005, Kerstetter and Graves 2006, Gilman et al. 2007, Diaz 2008, Sales et al. 2010). Japanese made tuna hooks of size 3.6 sun (5.0 $\mathrm{mm}$ wire diameter) straightened at approximately $564 \mathrm{lbs}(256.5 \mathrm{kgs}, n=3$, range 512-600 lbs; J Hall, unpubl data) of pull force. While our study demonstrated a transition from tuna to circle hooks on observed trips, there were no data on wire size for circle hooks historically used in the deep-set fishery. Assuming that the strongest 
circle hook currently used would be straightened at approximately 400 lbs (approximately $181 \mathrm{~kg}$ ) of force, the reduction in strength over time would represent at least $30 \%$. If management agencies consider regulating the wire diameter of circle hooks, the hooks used in our study represent a further strength reduction. The stronger $15 / 0$ control ( $4.5 \mathrm{~mm}$ wire) hook straightened at approximately $303 \mathrm{lbs}$, which is $46 \%$ weaker than a tuna hook. The weaker $15 / 0$ (4.0 $\mathrm{mm}$ wire) hook straightened at approximately $205 \mathrm{lbs}$, which is $32 \%$ weaker than the $4.5 \mathrm{~mm}$ wire circle hook and $64 \%$ weaker than a tuna hook. Hook strength was measured in our study, albeit there is subjectivity in defining when a hook was deformed to a degree in which mammal escapement was likely. Fishery managers could regulate hook shape (tuna, circle, and J-hooks), cross-section (round, rectangular), and wire diameter, although in reality the actual hook strength of a particular specification is highly variable based on the factory's source metal.

During the last decade, there have been a plethora of studies comparing hook types in pelagic longline fisheries with the objective of determining whether catches of target species can be maintained with a concurrent reduction in bycatch. The present study adds to the few published studies on longline trials using the same hook type with variable strength. Results indicated that target bigeye catch rate was not significantly different between hook types. However, this result is for the OctoberDecember trial period and may not be representative of other seasons when bigeye tuna have larger mean size. There was one observation of a FKW caught and released from a stronger $4.5 \mathrm{~mm}$ circle hook, thereby reducing the potential for serious injury and indicating that a $4.0 \mathrm{~mm}$ hook would not have been advantageous for this marine mammal interaction. Overall there was no significant reduction in catch rates of bycatch species by use of the weaker hooks. With regard to the bycatch potential of weak hooks, we concur with Bayse and Kerstetter (2010), who indicated the bycatch reduction potential of weak hooks is limited to species that can obtain relatively large mass, such as pilot whales, FKW, some marlins, and sharks, and may not be a viable option for reducing the catches of other large bycatch species interacting with the pelagic longline fishery, such as marine turtles, small marlins and sharks, manta rays, and sunfish. Future weak hook research for the Hawaii-based tuna fishery could assess target bigeye tuna catches when large fish are available to the fishery in a seasonal or spatial context. More generalized hook research could investigate pull strengths of different species over a range of size classes to determine strength characteristics in developing weak hooks.

\section{ACKNOWLEDGMENTS}

We express our appreciation to the Captains and crews of F/Vs KIMmY 1, KNOwLedge, LiHAU, and Miss LisA for adhering to experimental protocols. We also thank J Hall for conducting hook strength testing and the Pacific Islands Regional Observer Program for coordinating observers and maintaining data quality control. We acknowledge M McCracken for providing a computer subroutine for the randomization test. This research was partially funded by the New England Aquarium Consortium for Wildlife Bycatch Reduction and the Hawaii Longline Association provided an in-kind contribution of hooks, wire, and crimps. We thank three anonymous reviewers for their comments that improved the manuscript. 


\section{Literature Cited}

Bayse SM, Kerstetter DW. 2010. Assessing bycatch reduction potential of variable strength hooks for pilot whales in a western North Atlantic Pelagic Longline Fishery. J North Carolina Acad Sci. 126(1):6-14.

Bigelow K, Musyl M, Poisson F, Kleiber P. 2006. Pelagic longline gear depth and shoaling. Fish Res. 77:173-183. http://dx.doi.org/10.1016/j.fishres.2005.10.010

Bigelow K, Maunder M. 200\%. Does habitat or depth influence catch rates of pelagic species? CJFAS. 64:1581-1594.

Carretta JV, Forney KA, Oleson E, Martien K, Muto MM, Lowry MS, Barlow J, Baker J, Hanson B, Lynch D, et al. 2010. US Pacific marine mammal stock assessments: 2010. US Dep Commer, NOAA Tech Memo. NOAA-TM-NMFS-SWFSC-476. 352 p.

Curran D, Bigelow K. 2011. Effects of circle hooks on pelagic catches in the Hawaii-based tuna longline fishery. Fish Res. 109:265-275. http://dx.doi.org/10.1016/j.fishres.2011.02.013

Diaz G. 2008. The effect of circle hooks and straight (J) hooks on the catch rates and numbers of white marlin and blue marlin released alive by the US pelagic longline fleet in the Gulf of Mexico. N Am J Fish Manag. 28:500-506. http://dx.doi.org/10.1577/M07-089.1

Forney K, Kobayashi D, Johnston D, Marchettı J, Marsik M. 2011. What's the catch? Patterns of cetacean bycatch and depredation in Hawaii-based pelagic longline fisheries. Mar Ecol. 32:380-391. http://dx.doi.org/10.1111/j.1439-0485.2011.00454.x

Foster F, Bergmann C. 2010. 2010 interim report: update on Gulf of Mexico pelagic longline bluefin tuna mitigation research. NOAA Fisheries, Engineering and Harvesting Branch, SEFSC. $11 \mathrm{p}$.

Gilman E, Kobayashi D, Swenarton T, Brothers N, Dalzell P, Kinan-Kelly I. 2007. Reducing sea turtle interactions in the Hawaii-based longline swordfish fishery. Biol Conserv. 139:19-28. http://dx.doi.org/10.1016/j.biocon.2007.06.002

Gilman E, Kobayashı D, Chaloupka M. 2008. Ređūing seabird bycatch in the Hawaii longline tuna fishery. Endangered Spec Res. 5(2-3):309-323. http://dx.doi.org/10.3354/esr00133

Harley S, Hoyle S, Williams P, Hampton J, Kleiber P. 2010. Stock assessment of bigeye tuna in the western and central Pacific Ocean. WCPFC-SC6-2010/SA-WP-04, Nuku'alofa, Tonga, 10-19 August, 2010. http://www.wcpfc.int/node/2937.

Kerstetter DW, Graves JE. 2006. Effects of circle versus J-style hooks on target and non-target species in a pelagic longline fishery. Fish Res. 80(3):239-250. http://dx.doi.org/10.1016/j. fishres.2006.03.032

Leatherwood S, Reeves RR. 1983. The Sierra Club handbook of whales and dolphins. San Francisco, Sierra Club Books.

Manly B. 2007. Randomization, bootstrap and Monte Carlo methods in biology. 3rd ed. Chapman \& Hall/CRC, New York. 455 p.

McCracken ML, Forney KA. 2010. Preliminary assessment of incidental interactions with marine mammals in the Hawaii longline deep and shallow set fisheries. PIFSC Working Paper WP-10-001. Issued 27 April, 2010.

Nakamura EL, Uchiyama JH. 1966. Length-weight relations of Pacific tunas. In: Manar TA, editor. Proceedings, Governor's Conference on Central Pacific Fishery Resources. Honolulu, Hawaii. p. 197-201.

NMFS (National Marine Fisheries Service). 2010. Annual report on seabird interactions and mitigation efforts in the Hawaii longline fisheries for 2009. NMFS Pacific Islands Regional Office. Honolulu, HI. 50 p.

R Development Core Team. 2008. R: a language and environment for statistical computing. R Foundation for Statistical Computing, Vienna, Austria. ISBN 3-900051-07-0, Available from: http://www.R-project.org.

Sales G, Giffoni B, Fiedler F, Azevedo V, Kotas J, Swimmer Y, Bugoni L. 2010. Circle hook effectiveness for the mitigation of sea turtle bycatch and capture of target species in a Brazilian 
pelagic longline fishery. Aquatic Conserv: Mar Freshwat Ecosyst. 20:428-436. http://dx.doi. org/10.1002/aqc.1106

Suzuki Z, Warashina Y, Kishida M. 1977. The comparison of catches by regular and deep tuna longline gears in the western and central equatorial Pacific. Bull Far Seas Fish Res Lab. 15:51-89.

Uchiyama JH, Kazama TK. 2003. Updated weight-on-length relationships for pelagic fishes caught in the central North Pacific Ocean and bottomfishes from the Northwestern Hawaiian Islands. Pacific Islands Fish Sci Cent, Natl Mar Fish Serv, NOAA, Honolulu, HI 96822-2396. Pacific Islands Fish Sci Cent Admin Rep. H-03-01. 34 p.

Walsh W, Bigelow K, Sender K. 2009. Decreases in shark catches and mortality in the Hawaiibased longline fishery as documented by fishery observers. Mar Coast Fish: Dyn Mgmt Ecosys Sci. 1:270-282.

Watson JW, Epperly SP, Shah AK, Foster DG. 2005. Fishing methods to reduce sea turtle mortality associated with pelagic longlines. Can J Fish Aquat Sci. 62(5):965-981. http://dx.doi. org/10.1139/f05-004

DAte Submitted: 5 July, 2011.

Date ACCePted: 27 February, 2012.

Available Online: 11 May, 2012.

Addresses: (KAB) NOAA Fisheries, Pacific Islands Fisheries Science Center, 2570 Dole Street, Honolulu, Hawaii 96822. (DWK, MGD) Nova Southeastern University Oceanographic Center, 8000 North Ocean Drive, Dania Beach, Florida 33004. (JAM) NOAA Fisheries, Pacific Islands Regional Office, 1601 Kapiolani Blvd., Suite 1110, Honolulu, Hawaii 96814. Corresponding Author: (KAB) Telephone: (808) 983-5388, Email: <keith.bigelow@noaa.gov>.

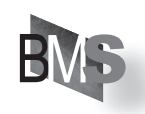

